\title{
Merging Activity as a Rational Explanation for the Long-Run Underperformance of IPO*
}

\author{
Patrick Sentis \\ University Montpellier, France **
}

The phenomena of IPO underpricing and underperformance are examined in the same rational model. In this model, underpricing is caused by the presence of uninformed investors. Low-type firms carry out an IPO under the same conditions as high-type firms. Instead of investing by themselves, the latter prefer to merge with a bidder, which entails their delisting from the market. The behavior of these firms provides a rational explanation for the underperformance phenomenon since only low-type firms remain on the market. Initial preliminary findings are consistent with the basic idea of the model. We show that when mergers occur, the monthly average return of the remaining firms is significantly negative, whereas the monthly average return is not significantly different from zero for the months without mergers. This result suggests that mergers induce a depreciation effect on the remaining firms and could be a source of underperformance.(JEL: G32, G34)

Keywords: initial public offerings, underpricing, underperformance, delisted, takeover, merger.

\section{Introduction}

The underpricing of initial public offerings (IPOs) is a well-documented

\footnotetext{
* The main idea of this paper was developed while I was a Visiting Scholar at the University of Texas in Austin. Many thanks to Andres Almazan, Robert Parrino, and Sheridan Titman at UT for their helpful comments and support. I would also like to thank William Dimovski, Ulrich Hege, Nancy Huyghebaert, and Edith Ginglinger for comments on previous versions of the paper presented at the IPO seminar 2001, AFFI 2001, and Multinational Finance Society 2006. I am grateful for the helpful comments of the referee. Thank you to Jay Ritter for providing me with his data. Research assistance from Romain Boissin has been appreciated. Financial support from the FNEGE is acknowledged. ** CR2M-University Montpellier I / GSCM-Montpellier Business School, University Montpellier, Avenue de la mer, CS 19519, 34960 Montpellier cedex 2, France, email: patrick.sentis@univ-montp1.fr.
}

(Multinational Finance Journal, 2009, vol. 13, no. 1/2, pp. 75-102)

(C) Multinational Finance Society, a nonprofit corporation. All rights reserved.

DOI: $10.17578 / 13-1 / 2-4$ 
phenomenon both empirically and theoretically. Empirically, there is no doubt that IPOs are underpriced on almost every market in the world (see for example, the international study by Loughran, Ritter, and Rydqvist (1994)). Several explanations for this underpricing have been proposed. ${ }^{1}$ In this paper, we specifically focus on two types of rational models: the "winner's curse" models (Rock (1986), Beatty and Ritter (1986), Carter and Manaster (1990)) and the signaling-based models (Allen and Faulhaber (1989), Grinblatt and Hwang (1989), Welch (1989)). In the winner's curse models, firms underprice their IPOs in order to compensate uninformed investors for an adverse selection. In the signaling-based models, underpricing appears as a signal from the high-type firm in order to get a higher price in subsequent seasoned equity offerings.

The model's first task in this paper is to consider the underpricing phenomenon as a result of a winner's curse. ${ }^{2}$ Meanwhile, the model shows that the offer depends on the firm's subsequent investment decision and therefore on the possibility of raising additional funds on the market. Then, in the same framework, the offer price depends on the presence of uninformed investors (winner's curse) and on the firm's future investment strategy (considered in the signaling-based models).

Examining another aspect of IPOs, several empirical studies document severe IPO underperformance (see for instance Ritter (1991) and Loughran and Ritter (1995)). Again, there is no consensus to

1. The underpricing of IPOs has generated extensive literature. The various approaches adopted to explain underpricing include those developed in this model (asymmetric information models and signaling models), as well as investor revelation/feedback models (Benveniste and Spindt (1989)), lawsuit avoidance arguments (Ibbotson (1975), Tinic (1988), Drake and Vetsuypens (1993)), information cascades (Welch (1992)), segmentation between primary and secondary markets (Mauer and Senbet (1992)), ownership dispersion arguments (Booth and Chua (1996)), the prospect theory of incremental rewards (Loughran and Ritter (2002)), and publicity effects (Demers and Lewellen (2003)). Ritter (2002) and Ritter and Welch (2002) give two extensive surveys of the IPO literature.

2. Michaely and Shaw (1994) find empirical evidence consistent with the winner's-curse hypothesis. They do not find empirical support for the signaling models. Moreover, Ritter (2002) argues that "it is possible that in the 1980s, when the average first-day return in the U.S. was 7\%, the Benveniste and Spindt (1989) dynamic information acquisition model and Rock's (1986) winner's curse model can explain much of the underpricing." As in Habib and Ljungqvist (2001), we use an adaptation of Rock's (1986) model to verify our main intuition. Our use of Rock's (1986) adverse selection rationale for underpricing is without loss of generality. All that is needed for our argument to hold is 1) a rational reason for underpricing 2) which is compatible with the existence of underperformance. 
explain this phenomenon. ${ }^{3}$ It seems that initially investors always act optimistically, by overpricing the IPOs, and later revise their beliefs. Teoh, Welch, and Wong (1998) show that IPO company managers systematically improve the firm's accruals and try to make results appear better than they really are. Investors gradually become aware of the firm's true value and accordingly revise their expectations downward. ${ }^{4}$ Our model takes this strategy into account. There are two types of firm, high-type and low-type: high-type firms are faced with a project which is profitable with certainty whereas the project of low-type firms is risky. In our model, low-type firms, which are not always profitable, can carry out an IPO under the same conditions as high-type firms, which are always profitable. The presence of uninformed investors makes the IPOs of low-type firms possible. These uninformed investors are fooled by these latter firms.

Subsequently, high-type firms have a choice between investing or being taken over by a friendly bidder. In the latter case, the firm is delisted because of the merger. ${ }^{5}$ As in Benninga, Helmantel, and Sarig (2005), high-type firms have an option to re-privatize by means of take-over bids. This feature provides a rational explanation for the underperformance phenomenon since the merger of high-type firms reduces the likelihood of investors being faced with high-value firms among firms that remain floated: low-type firms stay listed on the market while high-type firms progressively merge and are delisted. To our knowledge, this explanation for underperformance has not been tested as extensively as others. Seguin and Smoller (1997) report that $41 \%$ of IPOs are delisted after five years. In the same study, they show that merger activities explain one-third of delisted NASDAQ stock after five years. In an empirical study, Lewis, Seward, and Foster-Johnson (2000) show that underperformance could be explained by insufficient investor pessimism at the IPO date regarding the rate of surviving IPOs in the long term.

The main results of this model are as follows. We show that there is

3. There is an ever-increasing amount of literature explaining IPO stock return underperformance as related to venture capital (Brav and Gompers (1997)), investment banker recommendations, analysts' characteristics (Rajan and Servaes (1997), Teoh and Wong (1998)), and pseudo market timing Schultz (2003) among others.

4. From a sample of 5,764 IPOs, Ang and Brau (2003) show that insiders employ concealment strategies in an attempt to prevent outsiders from drawing unfavorable conjectures regarding the firm's value.

5. We argue, like Zingales (1995), that IPO can be viewed as a means by which to transfer control. 
a pooling equilibrium, where both high and low-type firms carry out an IPO at the same offer price. This pooling equilibrium implies underpricing. In the second period of the model, firms may either invest or not. We show that low-type firms always invest, whereas high-type firms either invest or are taken over, depending on the outcome of a deal with the bidder. The market revises its expectations when the firm invests. When the number of uninformed investors is high and there is a significant proportion of low-type firms, underpricing is expected to be high. Consequently, our model provides a rational explanation for the high underpricing observed during a high-uncertainty time period. Although the calculation of the offer price is based on the strategies of the two types of firms, underpricing is independent of these strategies and, thus, subsequent underperformance when it happens. By modeling within the same framework the underpricing phenomenon caused by the presence of uninformed investors and the underperformance process due to the merging and delisting of high- type firms, we show the absence of a link between the two phenomena. We argue that underperformance can be compatible with underpricing in a model where investors are rational. Finally, we deduct from the model that the delisting of merging firms should precede the delisting of busted firms.

A preliminary empirical study was conducted from the Ritter (1991)'s IPO sample. We are interested in this old data set for two reasons:

The strong underperformance phenomenon was identified from this sample for the first time;

Subsequent literature on IPO underperformance is based on this seminal finding.

Our empirical results are consistent with the main implications of our model: Merging firms which are subsequently delisted experience over-performance compared to other firms. Moreover, we observed that the merging activity creates a depreciation effect on the monthly average return of the remaining firms. In other words, the underperformance of the remaining IPO firms seems to be the result of the merging activity of some other IPO firms.

The remainder of the paper is organized as follows: Section II includes a description of the assumptions, sequence of actions and events, and the definition of equilibrium for the model. Section III presents the different equilibriums and their implications for firm pricing. Section IV discusses the model's empirical implications and compares results with the existing literature. Section V provides preliminary empirical evidence. Concluding remarks are contained in the last Section. 


\section{The Model}

\section{A. The Players}

We consider an economy of risk-neutral individuals in which two types (or qualities) of firm may carry out an IPO in order to raise funds for the future and invest in a project. The parameter $\tau \in\{H, L\}$ defines the type (or quality) of firm, where $\tau=\mathrm{H}$ refers to a high-type firm and $\tau=L$ to a low-type firm. The aggregate proportion of high-type and low-type firms are respectively $\pi$ and $1-\pi$. The high-type firm is faced with a project for which the net present value is $A$ with certainty. The amount of investment is $I$. In a low-type firm, the net present value of the project is $A$ with a probability $\gamma$ and 0 otherwise. The managers of a low-type firm do not know whether the project will be profitable or not until the final period of the model. They share the same knowledge of this profitability as the market which is embodied in the probability $\gamma$.

Let $\bar{v}$ and $\underline{v}$ respectively designate the high-value firms (high-type firm and low-type firm when its project is profitable) and the low-value firms (low-type firm when its project is unprofitable). From this, it is possible to define by $p(\bar{v})$ the aggregate proportion of high-value firms, i.e. firms for which the net present value of the project will be $A$, where:

$$
p(\bar{v})=\pi+(1-\pi) \gamma
$$

As in Rock (1986)'s model, there are two investor types. Uninformed investors are only aware of the aggregate proportion of high-type and low-type firms, $\pi$ and $1-\pi$ respectively. They know the probability $\gamma$ for the low-type firms to be profitable. They can thus infer the probability $p(\bar{v})$ of being faced with a high-value firm as defined above. Informed investors receive a signal $\mathrm{s}$ at the IPO date on the value of the firm. This signal is either "good" $(s=g)$ or "bad" $(s=b)$ with the following conditional probabilities:

$$
\begin{gathered}
\operatorname{Prob}(s=g \mid \nabla)=g_{\nabla}=1-b_{\bar{v}}, \\
\operatorname{Prob}(s=g \mid \underline{v})=g_{\underline{\underline{v}}}=1-b_{\underline{\underline{v}}}, \\
1>g_{\nabla}>0.5>g_{\underline{v}}>0
\end{gathered}
$$


IPO firms can subsequently merge with a bidder that is a publicly traded firm. The latter can only distinguish between a high-type firm $(\mathrm{H})$ and a low-type firm (L) by appropriate screening. However, the bidder cannot know with certainty whether a low-type firm will be profitable.

We model the game played by managers, bidder firms, and investors in a three- period, four-date, multi-stage framework. The market is both passive and efficient. Investors purchase an offering only if, on the basis of current information, the expected value marginally exceeds the price. Firm manager-owners and bidder firms are active players. The former maximize the expected value of their wealth, which is composed of that part of the firm sold during the IPO and the rest of the firm still held by them after the IPO. The latter maximizes the net present value of their acquisition.

\section{B. The Actions}

The sequence of events is depicted in table 1 .

At Period 0, the firm defines exogenously the proportion $\beta$ to sell and endogenously the offer price $P_{0}$, and it issues its IPO. Informed investors have received the signal $s$ at this date. If the signal is $b$, informed investors do not participate in the offer and uninformed investors receive $100 \%$ of their demand. If the signal is $g$, informed investors bid such that total demand, $\mathrm{N}$, exceeds the proportion of firm offered $\beta(N>\beta) .{ }^{6}$ In this case, uninformed investors are rationed and get a proportion $\beta / N$ of their demand. At Period 1 , uninformed investors receive the same signal that was privately held by informed investors at 0 . So, at 1 , the investors are faced with the same information set. The shares are marketed according to the information publicly available at their expected post-IPO value, $P_{1}$. At Period 2, the growth option expires. The high-type firm could either invest or not, or be taken over by a friendly bidder. We suppose that this take-over leads to a merger between the high-type firm and the bidder. Once merged, the bidder is supposed to invest in the firm's project by spending $I$, the amount initially held in cash. The value of the bid, $M$ for a $H$-type firm, is considered endogenous and results from a deal between the bidder and the IPO firm in Stage 2-01. Since the bidder is able to distinguish between a high-type and a low-type firm, it attempts to take advantage of the undervaluation of high-type firms on the secondary market by

6. In extenso, $N$ designates the proportion of the whole firm demanded by all of the investors. 
TABLE 1. The Sequence of Events

At Period 0, IPO date

Informed investors receive signal $s$. Issuing portion $\beta$ of the firm at a price of $P_{0}$.

At Period 1, flotation

Signal $s$ becomes common knowledge. Shares are marketed at their expected post-IPO value, $P_{1}$.

At Period 2, investing and merging strategies

Stage 2-01: Bargaining process between the bidder and IPO high-type firms.

Stage 2-02: Firms decide to invest or to be taken over and merged.

Delisting of merging firms; $P_{2}$ is the resulting price.

At Period 3, information disclosure

All information is public and final cash flows are distributed to shareholders.

submitting a bid to them. ${ }^{7}$ In stage 2-02, the firm must decide whether to invest or be taken over. The market formulates its subsequent belief according to the firm's action $O \in\{I, N I, T O\}$, where $I$ stands for investment, $N I$ for no investment, and $T O$ for take-over. The price of stock at this period, $P_{2}$, results in this revision. At Period 3, all information is public and final cash flows are distributed to shareholders.

\section{The Equilibrium Concept}

Let $\sigma_{0}\left[P_{0} \mid \tau\right]$ represent the strategy of a firm of type $\tau \in\{H, L\}$ in Period 0 , and let $\sigma_{2}[O \mid \tau]$ represent the strategy of a firm of type $\tau$ in Period 2 after a specific strategy in Period 0. Initially, the market's prior beliefs are embodied in the probability $\pi \in[0,1]$ that a firm is a high-type $H$ and $\gamma \in[0,1]$ that a low-type firm $L$ will be profitable. Consequently, the market's prior probability, that a firm has a high value $\bar{v}$, is defined by the probability $p(\nabla)$ as previously established above.

We define by $p_{1}\left(\bar{v} \mid P_{0}, s\right)$ the market's belief in Period 1 that the firm is of high-value after having observed the offer price $P_{0}$ at the IPO

7. This type of acquisition is usually classified as a financial acquisition because it does not involve operating synergies. As formulated later in the game between the bidder and IPO firm, in a financial acquisition, the bidder believes that the price of the target (IPO firm) is less than the intrinsic value of the firm's assets. 
date and the signal $s \in\{g, b\}$ at Period 1. Finally, let $p_{2}\left(\bar{v} \mid P_{0}, s, O\right)$ denote the market's belief in Period 2 that the firm is high-value after having observed the offer price $P_{0}$, the signal received $s$, and the firm's operation $O$.

We employ the Bayesian equilibrium concept to specify the link between market beliefs and firm strategies. An equilibrium is a set of strategies $\sigma_{0}, \sigma_{2}$ and subsequent market beliefs, $p_{1}, p_{2}$ such that (1) at each period the strategy of a firm of type $\tau$ is one based on wealth maximizing, given their own information, on past and future wealth-maximizing strategies, and on market beliefs, and (2) at each period the market's beliefs about firm type are revised according to Bayes' rule after firm strategies have been observed.

\section{Conditions for the Co-Existence of Underpricing and Underperformance}

After having presented the offer price and underpricing calculations, we describe the bargaining process between the high-type firm and the bidder. We then show existing underperformance conditions. The model's equilibrium is finally identified.

\section{A. The Offer Price and Underpricing Phenomenon}

To infer the offer price, we must represent the value of the high-type and low-type firm according to their future strategies. To simplify, firms can either invest by themselves or be taken over and invest via the acquirer. Let $y \in[0,1]$ and $e \in[0,1]$ respectively represent the proportion of high-type firms and low-type firms which invest during Period 2. We can then define the expected value of a firm, knowing its type, as shown in the table 2.

Let us now consider what the bid $M_{H}$ and $M_{L}$ will be to withdraw all shares from the market in order to complete the merger. At period 2, the bidder purchases $1-\beta$ of the firm from the manager-owners. The remaining $\beta$ must be purchased from outside shareholders in order to complete the merger and delist the firm. Since the take-over activity is fully informative and reveals the value of the firm, outside shareholders will require an amount $A$ to persuade them to sell their stocks. Therefore, whatever the strategy adopted by firms, from an outside shareholder's point of view, high-value and low-value firms will respectively be worth $A$ and 0 . 
TABLE 2. Market Value of Firms is Type-Conditional.

\begin{tabular}{cc}
\hline High-type firm $\left(P_{1}{ }^{H}\right)$ & Low-type firm $\left(P_{1}{ }^{L}\right)$ \\
\hline$y A+(1-y) M_{H}$ & $e A \gamma+(1-e) M_{L}$ \\
\hline
\end{tabular}

Note: The market values of high-type and low-type firms are described. Their value depends on their investment strategy in Period 2. $y \in[0,1]$ and $e \in[0,1]$ respectively represent the proportion of high-type firms and low-type firms which invest during Period 2. When the firm does not invest, it can be taken over by an acquirer at the price of $M_{H}$ and $M_{L}$ respectively for a high-type and a low-type firm.

The market revises its expectations regarding firm value after having observed the signal $s$. The market's updated beliefs follow Bayes' rule. In order to infer the offer price $P_{0}$ at the IPO date, we need to define the probability, $p_{1}(\bar{v} \mid s)$, that investors be faced with a high-value firm according to the observed signal at Period 1:

$$
\begin{aligned}
& p_{1}(\bar{v} \mid g)=\frac{g_{\bar{v}} p(\bar{v})}{g_{\bar{v}} p(\bar{v})+g_{\underline{v}}(1-p(\bar{v}))}=1-p_{1}(\underline{v} \mid g) \\
& p_{1}(\nabla \mid b)=\frac{b_{\bar{v}} p(\bar{v})}{b_{\bar{v}} p(\bar{v})+b_{\underline{\underline{v}}}(1-p(\bar{v}))}=1-p_{1}(\underline{v} \mid b)
\end{aligned}
$$

The price $P_{0}$ at which shares are sold to investors must be that upon which uninformed investors would expect, on average, to break even, otherwise they would not subscribe to the IPO.

$$
\begin{gathered}
\frac{\beta}{\mathrm{N}} p(g)\left[p_{1}(\bar{v} \mid g)\left(A-P_{0}\right)-p_{1}(\underline{v} \mid g) P_{0}\right] \\
+(1-p(g))\left[p_{1}(\bar{v} \mid b)\left(A-P_{0}\right)-p_{1}(\underline{v} \mid b) P_{0}\right]=0 \\
\text { with } \quad p(g)=g_{\bar{v}} p(\bar{v})+g_{\underline{v}}(1-p(\bar{v}))
\end{gathered}
$$

The first element on the left side of this equation is equal to the expected wealth of the uninformed investors when the informed investors have received a good signal $(s=g)$ and subscribed to the offer. In this case, the uninformed investors are rationed for the amount $\beta / N$. The second element of the same equation is the expected wealth of the 
uninformed investors when the informed investors have received a bad signal $(s=b)$. In this case, informed investors do not participate in the offer and uninformed investors receive $100 \%$ of their demand. $P_{0}$ is therefore such that:

$$
P_{0}=\frac{A\left[\frac{\beta}{N} p(g) p_{1}(\bar{v} \mid g)+(1-p(g)) p_{1}(\bar{v} \mid b)\right]}{1-p(g)\left(1-\frac{\beta}{N}\right)}
$$

We observe that the more subscribed the offer $(N \mathrm{big})$ and/or the fewer shares sold ( $\beta$ low), the lower the offer price.

To calculate the initial return, $I R$, we need to define the expected post-IPO price, $P_{1}$, at which the shares are sold on the secondary market. At Period 1, all investors receive the signal, $s$, which is no longer the private information of informed investors. Therefore, the probability that the firm is of high-value depends on the signal received as already shown in 5 and 6.

If the signal s is $\operatorname{good}(s=g)$ ex-post, the price $P_{1 \mid g}$ is:

$$
P_{1 \mid g}=p_{1}(\bar{v} \mid g) A
$$

However, if the signal $s$ is bad $(s=b)$ ex-post, the price $P_{1 \mid b}$ is:

$$
P_{1 \mid b}=p_{1}(\bar{v} \mid b) A
$$

It is possible to define the price $P_{1}$, ex-ante, before the disclosure of the signal as:

$$
P_{1}=p(g) P_{1 \mid g}+(1-p(g)) P_{1 \mid b}=p(\bar{v}) A
$$

By using $P_{0}$ and $P_{1}$ as defined respectively in 8 and 11 , we can compute the ex-ante initial return $(I R)$ :

$$
I R \equiv \frac{P_{1}-P_{0}}{P_{0}}
$$

We can easily show that $I R>0$ when $\beta / N<1$. This result means that 
there is underpricing when the offer is rationed. Of course, the more the offer is rationed $(\beta / N$ low), the higher the underpricing.

Proposition 1: There is underpricing when $\beta / N<1$.

Proof: see appendix.

After some simplification, the initial return $I R$ as expressed in 12 can be reduced to:

$$
I R=\frac{(1-\pi)(1-\gamma)\left(g_{\nabla}-g_{\underline{V}}\right)(1-\beta / N)}{1-g_{\nabla}(1-\beta / N)}
$$

From this later expression, it appears that the initial return (and thus the underpricing) decreases in $\pi$ and $\gamma$. It means that the higher the probability that investors are faced with a profitable firm, the less uninformed investors need to be compensated for asymmetric information. More interestingly, we observe that underpricing depends on the precision of the signal received by informed investors $g_{\sigma}-g_{v}$. The greater this difference, the more precise the signal and stronger the underpricing. Indeed, when the signal is very precise, the asymmetric information between informed and non informed investors at the IPO date is very strong. The latter thus need more underpricing to offset this important asymmetric information.

\section{B. An Underperformance Context}

To study the conditions of underperformance between Periods 1 and 2, we need to calculate the price of stock, $P_{2}$, at Period 2. This price depends on the investment strategies followed by each firm.

To analyze the order relation between $P_{0}, P_{1}$, and $P_{2}$ (and thus the conditions in which underpricing and underperformance co-exist), manager-owner wealth functions for each firm must be described according to each possible strategy.

\section{Manager-Owner Wealth}

Remember that managers issue an IPO in order to invest in the future. After the IPO, there is no subsequent sale of their shares. However, we assumed that the firm had experienced no financial slack. Thus, the investment required raising funds on the market for an amount of $I$.

When a high-type firm invests, manager-owner wealth is given as: 


$$
W_{H, s}^{I}=\beta P_{0}+(1-\beta) \frac{P_{2}}{P_{2}+I}(A+I), \text { for } s \in\{g, b\}
$$

This wealth consists of IPO proceeds (the first term on the right hand side) and the share of firm value held by manager-owners after funds have been raised to the amount of $I$ and invested (the second term on the same side). This second part takes a potential informational asymmetry between firm and financial market into account, as in Myers and Majluf (1984). The manager-owner wealth of a profitable low-type firm has the same expression as above. When the project is profitable the low-type firm will invest.

If the high-type firm does not invest, it is taken over by a bidder and the implication of this operation for the wealth of manager-owners is given by:

$$
W_{H, s}^{T O}=\beta P_{0}+(1-\beta) M_{s}, \text { for } s \in\{g, b\}
$$

The wealth functions, as expressed in 14 and 15, will take on a specific form for high-type firms depending on their strategy and the signal received. It appears that the high-type firm's choice between investing or being taken over will be driven by the bid, $M_{s}$, submitted by the bidding firm. From 14 and 15, this bid must satisfy the following constraint to incite high-type firm manager-owners to sell their shares:

$$
M_{s}=\frac{P_{2}}{P_{2}+I}(A+I)
$$

The manager wealth of the low-type firm that is not profitable is described by the two following equations when the firm invests and does not invest respectively:

$$
\begin{gathered}
W_{L, s}^{I}=\beta P_{0}+(1-\beta) \frac{P_{2}}{P_{2}+I} I \\
W_{L, s}^{N I}=\beta P_{0}
\end{gathered}
$$

From these equations, we can immediately conclude that a low-type 
firm always prefers to invest $\left(W_{L, s}^{I}>W_{L, s}^{N I}\right)$.

Proposition 2: $\forall\left\{\pi, \gamma, g_{\nabla}, g_{\underline{v}}\right\} \in[0,1]$, and $\forall\{A, I\} \in R^{+}, e=1$ : The low-type firm will always issue and adopt an investment strategy at Period 2 whatever the signal $s \in\{g, b\}$ received.

The market revises its expectations regarding the quality of the firm after it has observed the firm's decision to invest or not. This second market belief update also follows Bayes' rule. From proposition 2, we can define, $p_{2}(\bar{v} \mid s, O)$, the market's belief that the firm is one of high-value after having observed the signal, $s$, and the firm's operation, $O$.

$$
\begin{gathered}
p_{2}(\nabla \mid g, O)=\frac{[\pi y+(1-\pi y) \gamma] g_{\bar{V}}}{[\pi y+(1-\pi y) \gamma] g_{\bar{V}}+[1-\pi y-(1-\pi y) \gamma] g_{\underline{\underline{v}}}} \\
p_{2}(\bar{v} \mid b, O)=\frac{[\pi y+(1-\pi y) \gamma] b_{\bar{v}}}{[\pi y+(1-\pi y) \gamma] b_{\bar{v}}+[1-\pi y-(1-\pi y) \gamma] b_{\underline{v}}}
\end{gathered}
$$

Ex-post, the price of the stock $P_{2 \mid s, O}$ will reflect this expectation, such that:

$$
P_{2 \mid s, O}=p_{2}(\bar{v} \mid s, O) A s \in\{g, b\}
$$

As for the price $P_{1}$, it is still possible to define an ex-ante price $P_{2}$ :

$$
P_{2}=p(g) P_{2 \mid g, O}+(1-p(g)) P_{2 \mid b, O}=[\pi y+(1-\pi y) \gamma] A
$$

This price is driven by the high-type firm's decision, $y$, either to invest $(y=1)$ or to be taken over $(y=0)$. Hence, we need to briefly describe the bargaining game played by the bidder firm and the high-type IPO firm at Period 2 in stage 2-01.

\section{The Bargaining Game Between Bidder Firm and High-Type Firm}

This game is a proper subgame of the whole game played by firms and investors. ${ }^{8}$ In this subgame, information is complete and the players

8. Informally, a proper subgame is a portion of a game that can be analyzed as a game 
involved are the bidder firm, which is unique, and both type of firms. The bidder firm is supposed to be risk adverse. It knows the type of firm for which it makes a bid, through appropriate screening. As the bidder is risk adverse, it will address its offer only to high-type firms. The merger offer is perceived as friendly. Nevertheless, the consent of the target management (IPO firm) is still required in order to complete the operation. We use the cooperative Nash bargaining solution with the bidder and the high-type firm having equal weights in the negotiation. As soon as the target management of the high-type firm accepts the offer to sell their portion $(1-\beta)$ of the firm at price $M_{s}$, the merger is completed by the purchase at price $A$ of the remaining shares $\beta$ floated on the market. ${ }^{9}$ Once the merger is achieved, the acquiring firm undertakes the project inherited from the high-value firm and receives additional assets valued at $A .{ }^{10}$ The incremental wealth of the bidder, denoted by $W_{B i d}$, resulting from the operation is therefore given by:

$$
W_{B i d}=A-\left(\beta A+(1-\beta) M_{s}\right)
$$

The bidder will define $M_{s}$ to solve

$$
\max _{M_{s}}(1-\beta)\left(A-M_{s}\right)
$$

$$
\text { subject to } A \geq M_{s} \geq \frac{P_{2}}{P_{2}+I}(A+I) \text { from constraint } 16
$$

The Nash bargaining solution to this program is trivial. The bid $M_{s}^{*}$ must satisfy:

$$
M_{s}^{*}=\frac{\left[A+\frac{P_{2}}{P_{2}+I}(A+I)\right]}{2}
$$

We can easily verify that, $M_{s}^{*}<A$ allowing the bidding firm to obtain

in its own right (Fudenberg and Tirole (1995)).

9. The take-over activity on IPO is a perfectly revealing signal of firm type for the market.

10. We suppose that the investment is funded by free cash flow from the acquiring firm. 
a gain from the transaction. This inequality is satisfied if $P_{2}<A$ which is always true for all $s \in\{g, b\}$.

These results are summarized in the following proposition:

Proposition 3: The following strategies characterize a Nash bargaining solution at Period 2 between the high-type firm and the bidder, for $\beta$ given in $[0,1]$, for all $\{A, I\} \in R^{+}$, and for all $s \in\{g, b\}$ : The bidder submits $M_{s}^{*}$ to the high-type firm. The high-type firm accepts the bid and merges with the bidder.

Proof: From the discussion above.

These insights into the behavior of the bidder and high-type firms enable us to solve the equilibrium of the whole game.

\section{Equilibrium of the Model: Definition and Properties}

First, we define the equilibrium of the whole game and test its robustness. Secondly, the proprieties of this equilibrium are described.

\section{The Equilibrium}

The definition of the equilibrium. The definition of the equilibrium follows on from the previous section.

Proposition 4: The following set of strategies characterizes a perfect Bayesian Nash equilibrium:

(i) At Period 0, the high-type firm issues a part of its share $\beta$ at the offer price $P_{0}$. The low-type firm issues the same part $\beta$ at the same price $P_{0}$, regardless of the signal $s \in\{g, b\}$ received.

(1) Investor beliefs:

$$
\begin{aligned}
& p_{1}(\bar{v} \mid g)=\frac{g_{\bar{\nabla}} p(\bar{v})}{g_{\bar{v}} p(\bar{v})+g_{\underline{v}}(1-p(\bar{v}))}=1-p_{1}(\underline{v} \mid g) \\
& p_{1}(\bar{v} \mid b)=\frac{b_{\bar{v}} p(\bar{v})}{b_{\bar{v}} p(\bar{v})+b_{\underline{v}}(1-p(\bar{v}))}=1-p_{1}(\underline{v} \mid b)
\end{aligned}
$$

(2) Strategies of high-type and low-type firms:

$$
\sigma_{1}\left[\left(P_{0}, \beta\right) \mid H\right]=\sigma_{1}\left[\left(P_{0}, \beta\right) \mid L\right]=1
$$

(ii) At Period 2, the low-type firm always invests. The high-type firm 
prefers to be taken over and merge at a bid $M_{s}^{*}, s \in\{g, b\}$ as defined in proposition 3 .

(1) Investor beliefs:

$$
\begin{aligned}
& p_{2}(\bar{v} \mid g, T O)=\frac{\gamma g_{\bar{v}}}{\gamma g_{\bar{v}}+(1-\gamma) g_{\underline{\underline{v}}}} \\
& p_{2}(\nabla \mid b, T O)=\frac{\gamma b_{\bar{\nabla}}}{\gamma b_{\bar{v}}+(1-\gamma) b_{\underline{\underline{v}}}}
\end{aligned}
$$

(2) Strategies of high-type and low-type firms:

$$
\begin{gathered}
\sigma_{2}[T O \mid H]=1 \\
\sigma_{2}[I \mid L]=1
\end{gathered}
$$

Proof: See appendix.

The results of proposition 4 indicate firms sell the same amount of shares at the IPO at the same price, irrespective of type. Moreover, the low-type firm always invests at Period 2, whereas the high-type firm will always prefer to be taken over. ${ }^{11}$

\section{The Underperformance Proprieties}

The first part of the proposition 4 explains the existence of underpricing. Under- pricing is caused by the presence of uninformed investors who cannot distinguish between low-value firms and high-value firms as shown in section III, A. The second part of the proposition provides justification for subsequent underperformance. At Period 2, high-type firms prefer to merge with the bidder. This merging implies a delisting of the firm. Therefore, at Period 2, by observing the firm's strategy, market investors can infer that it is a low-type firm that invests, knowing that high-type firms have been delisted by merging.

Underperformance, UP, can be measured from the ex-ante price $P_{1}$ and $P_{2}$ as calculated in equations 11 and 22:

11. This equilibrium stands up to robustness tests in the spirit of the Cho-Kreps argument. Proof is available on request. 


$$
\begin{aligned}
U P & =\frac{P_{2}}{P_{1}}-1 \\
& =\frac{\pi y+(1-\pi y) \gamma}{\pi+(1-\pi) \gamma}-1
\end{aligned}
$$

As we can see, underperformance depends on the decision of the high-type firm $y$. From proposition $4, y=0$, underperformance is:

$$
U P=\frac{\pi(\gamma-1)}{\pi+(1-\pi) \gamma}
$$

As $y<1, U P$ is negative and characterizes an underperformance situation. Of course, if high-type firms have chosen to invest $(y=1)$, there would have been no underperformance. Simple first order derivatives according to $\gamma$ and $\pi$ show that performance, $U P$, increases in $\gamma$ and decreases in $\pi$. The intuition is that the more numerous high-type firms are ( $\pi$ high), the more numerous delisting will be and the more severe underperformance will be. However, the more numerous profitable firms are among low-type firms ( $\gamma$ high), the more numerous profitable firms will remain on the market and the less severe underperformance will be.

\section{Related Literature and Empirical Content of the Model}

The empirical implications of the model are now summarized and related to the existing literature.

Implication 1: Underperformance is related to the delisting of some firms in a large market. According to our model, underperformance was caused by the delisting of the high-type firm that merged with a bidder. To our knowledge, this rational explanation for underperformance has never been provided and tested in previous studies. This leads us to assume that the market is wide enough to accommodate a sufficient number of potential bidders willing to purchase a high-type firm, which is the case on the American markets. Consistent with this point, on the European markets, which are smaller than the American markets, underperformance seems to be less prevalent (Espenlaub, Gregory, and 
Tonks (2000) and Stehle, Ehrhardt, and Przyborowsky (2000)). Moreover, our model shows that underperformance could be compatible with underpricing in an efficient market. In a related work, Schultz (2003) argues that more IPOs follow successful IPOs. Thus, the last large group of IPOs would underperform and be a relatively large fraction of the sample. Consequently, the level of ex-post underperformance is not indicative of any market inefficiency.

Implication 2: Quality of delisted firms. The model predicts that only high-type firms are permitted to merge with a bidder and are delisted accordingly. Merging firms, which are supposed to be high-type firms, should thus exhibit better financial and operating performance than non-merging firms. Moreover, the model suggests that the bidder has special information about the target. Consequently, the bid is likely to convey information to the market about the value of the target as a stand-alone company. In take-over literature, some studies try to obtain insight into the extent to which special information about the target is revealed by examining stock price reactions when offers are terminated. The most famous of them (Bradley (1980), Dodd (1980), and Bradley, Desai, and Kim (1983)) show that share prices tend to decline subsequent to the failure of an initial bid, but the prices generally stay considerably above the stock price for the target that existed before the bid. This evidence could indicate that the bidders have some special information because, if the gains were all due to either improved management or synergies, the stock price should theoretically drop back to its original level after a failed bid.

Moreover, from a large-scale empirical study, Aggrawal and Jaffe (2003) conclude that the conventional view that targets perform poorly is not supported by the data. Concerning the IPO, only Bhabra and Pettway (2003)'s study reports that firms that merged showed significant stock return performance compared to those that continued to trade. These firms are significantly older and larger compared to firms that were still trading. This result is consistent with our model. However their sample counts 272 IPOs and only 14 merging firms. To our knowledge, no other study specifically examines the financial and operating performance of target firms which are recent IPOs.

Altogether, these findings support our hypothesis indicating that bidders have special information about IPO firms.

Implication 3: Quality of remaining firms. The merging activity acts as a signal to the market. As soon as investors perceive the merger and investment strategies of the firms, they can figure out which firms are still listed and price them accordingly. Consequently, the revision of 
their expectations regarding the remaining firms occurs after observation of these strategies. We should then verify that the delisting of merging firms either precedes the delisting of busted firms, or occurs before a drop in average stock return on a sampling of IPOs.

Moreover, in the model, the firm that remains on the market could be either a high-value (low-type firm which became profitable) or low-value firm (low-type firm not profitable). The low-value firm is condemned to be busted and delisted because it lacks a profitable project. Therefore, in the long run the only active firm will be one of high-value. The performance of acquired and active IPOs must not be significantly different a posteriori. This is consistent with the findings of Lewis, Seward, and Foster-Johnson (2000) where an excess of returns for acquired and active IPOs are statistically indistinguishable from zero over the long return horizon. However, the aforementioned authors are unable to explain why there is a lag between issue date and investor recognition of operating performance problems. According to our model, the recognition of the low-type firm will occur as soon as the first mergers of high-type IPOs occur.

Implication 4: Other related topics and literature. Underpricing: In our model, underpricing is related to the presence of uninformed investors. The more important the demand, the more important the underpricing. The greater the probability that the firm is high-type and/or the greater the probability that the low-type firm is profitable, the lower the extent of the underpricing. This is consistent with the Rock (1986) model and the evidence of Beatty and Ritter (1986) which links underpricing to the risk of the firm.

Moreover, our findings suggest that there may be times during which the proportion of high-value firms issuing IPOs is greater than for other kinds of firms. Consistent with this, Ritter (1984) documents the existence of "hot issue" and "cold issue" markets, across which the extent of underpricing differs significantly.

On the other hand, during the internet bubble, the demand for IPOs shares emanating from uninformed investors was very strong. Meanwhile, many low-type firms were issuing before having even made any profit. We think that the conjunction of these two features explains the strong underpricing observed at that time consistent with the prediction of our model. Loughran and Ritter (2002) explain this underpricing by arguing that underwriters took advantage of these fortuitous circumstances to severely underprice many IPOs. Again, this is consistent with our explanation.

Causality between underpricing and underperformance: 
Underpricing does not depend on the firm's future investment policy; there is no exclusive relationship between underpricing and underperformance. Ex-post, underpricing could exist without subsequent underperformance, and conversely.

This implies that there are specific situations where underperformance is associated with underpricing. This is consistent with the empirical results of Ritter (1991) and Levis (1993).

Investment and selling policies of IPO firms: As in Zingales (1995), the purpose of the IPO could be the takeover by another firm and a means by which to maximize the proceeds from a transfer of control. In our model, when high-type firms are too undervalued by the market, manager-owners prefer to sell the firm at a discount rather than invest. This behavior implies a delisting of the firms that merge with a bidder. Takeover or investment appear to be an alternative strategy for undervalued IPO firms.

However, Mello and Parsons (1998) argue that issuers can use valuation information, generated by IPO aimed at dispersed shareholders, in subsequent negotiations with potential buyers of controlling blocks. Conversely, we argue that information is generated later when IPO firms are taken over by a bidder. This information concerns the merging firms and also the remaining firms. ${ }^{12}$

\section{Preliminary Evidence on IPO Merging Activities}

We propose to give some empirical insights to our three main implications (Implications 1, 2, and 3). From these implications, only good IPOs are willing to merge. We could expect that the merging firms from the IPOs would present a strong long-run performance. Meanwhile, we showed in the model that the delisting of the merging firm implies underperformance for the remaining firms. To test this result, we examined the relationship between the size of the merging activity and the average return of those IPO firms that remain on the market.

12. Brau, Francis, and Kohers (2003) address the private firm's choice to access public equity markets, between an IPO and a takeover by a publicly traded acquirer. They show that takeovers are a substitute for some private U.S. firms, especially in non high-tech and high market-to-book industries. However, they do not address the choice between investment and take-over shortly after the IPO as we did theoretically in this paper. 


\section{A. Sample Collection and Performance Measures}

We obtained data for 1,526 operating company IPOs from 1975 through 1984 from Jay Ritter. To evaluate the long-run performance of initial public offerings, we used, like Ritter (1991), the cumulative average adjusted returns (CAR) calculated with monthly portfolio rebalancing. The adjusted returns are computed using a matching firms benchmark. The matching firms are represented by securities that are to some extent matched by industry and market capitalization with each IPO. The benchmark-adjusted return to stock $i$ in event month $t$ is defined as

$$
a r_{i, t}=r_{i, t}-r_{m, t}
$$

The average benchmark-adjusted return on a portfolio of $n$ stocks for event month $t$ is the equally-weighted arithmetic average of the benchmark-adjusted returns:

$$
A R_{t}=\frac{1}{n} \sum_{i=1}^{n} a r_{i, t}
$$

The cumulative benchmark-adjusted aftermarket performance from event month $q$ to event month $s$ is the summation of the average benchmark-adjusted returns:

$$
C A R_{q, s}=\sum_{i=q}^{s} A R_{t}
$$

As previously indicated, Ritter (1991) found a very strong underperformance in this sampling of firms, with negative cumulative average matching firm-adjusted returns of $29.13 \%$.

\section{B. Identification of Delisting Firms and Description of Performed Tests}

Firstly, we identified 272 firms delisted during the 36 months of the study period. Secondly, we looked for the reasons behind these delistings on the CRSP database. We collected the date of merger and the attitude of transaction (hostile or friendly) from SDC platinum. Finally, we conducted several tests involving the delisted firms.

Among the 272 delisted firms, 106 firms were delisted because of 
merger activity. We classify an issuer as an acquired IPO if the firm possesses a delist code between 200 and 301 or 591 (Underlying assets have merged with another company). Only 8 firms were delisted after bankruptcy whereas 144 firms were delisted because of non-respect of market requirements. No code is available for 14 firms delisted. 1,254 firms are still listed after 36 months of flotation. Consequently, we count 1,420 firms as non-merged IPOs.

Of the 106 firms delisted because of merger activity, 82 transactions were friendly, 2 were hostile, and 22 were classified as not applicable (2), neutral (2) and missing data (18). This first descriptive statistic is consistent with our hypothesis that IPO firms merge mainly after a friendly transaction. ${ }^{13}$

The first test consists of calculating the cumulative adjusted average return on the 36 months for merged IPOs and non-merged IPOs. ${ }^{14}$ By exhibiting differences in long-run performance between these two groups, this test will help verify empirical implications 2 and 3 in our model.

A second test consists of measuring the strength of the relationship between the merger activity and the decline of the average return for the non-merged firms. In order to perform this test, we calculated the average adjusted return of IPOs for each event month. The observation period counts 155 months (from January 1975 to November 1987). We distinguished months with merging activity from months without such activity. For months with merging activity, the average adjusted return of IPOs was calculated by excluding the returns of IPO firms that merged during the month. For instance, during October 1978, two IPOs merged. The average adjusted returns for this month, which was $-0.9 \%$, was calculated by excluding the adjusted returns of these two IPOs. This exclusion made it possible to assess the impact of merger activity on non-merged firms. Finally, we computed the average returns of months with merger activity and the average returns of months without merger activity. In order to keep statistical significance, only months with more than 50 IPO firms floated were averaged. To be consistent with our

13. Shleifer and Vishny (1990) point out that many takeovers in the ' 80 s were hostile but especially the large ones; the reason is that these big firms were too diversified and inefficient. At the same time, they underline that "there was a sharp increase in the number of friendly-related acquisitions" in response to the changed antitrust policy. Moreover IPO firms are known to be smaller than firms already listed. These facts explain why the proportion of friendly takeovers is particularly high in this sample.

14. The methodology used to calculate the average return is similar to the one used in Ritter's study as previously described. 


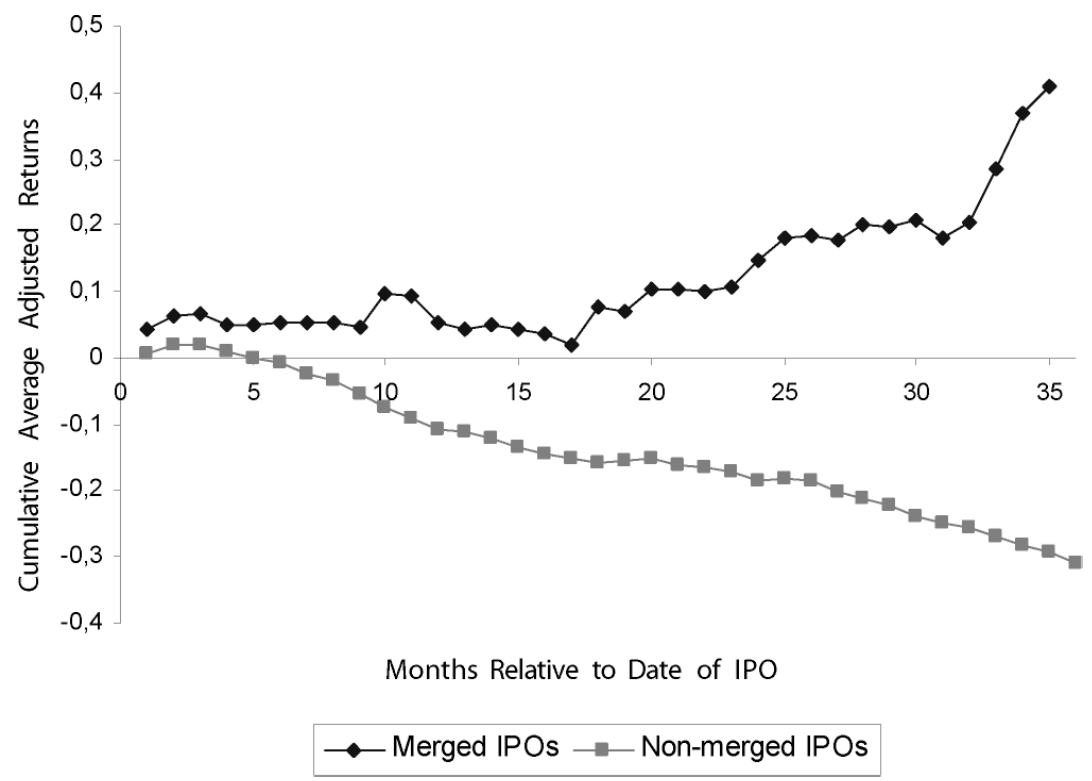

FIGURE 1.- Cumulative Adjusted Abnormal Returns for Initial Public Offerings which Merged During the Observation Period

model, we classified months where there was a non-friendly merger as a month without merger. As suggested by our implication 1, if the delisting of the merged firms conveys negative information on the quality of the remaining firms, the average returns of months with merger activity should be significantly negative. Conversely, the average return of months without merger should not be significantly different from zero.

\section{Preliminary Empirical Results}

Figure 1 plots cumulative average matching-firms adjusted returns for IPO firms which merged and for non-merged IPO firms. Depending on each group, the resulting CARs display different patterns. Long-run performance is particularly negative for non-merged IPO firms whereas the merged firms exhibit a strong positive cumulative average return. This result is consistent with the merged firms being the best in the sample. It is consistent with empirical implications 1 and 2 .

The table 3 presents the results of our second test. We observe that for months with merger activity, the average adjusted return is significantly negative. Conversely, the average adjusted return of 
TABLE 3. Average Return of Months According to Merging Activity.

\begin{tabular}{cc}
\hline $\begin{array}{c}\text { Mean and median returns of } \\
\text { months without mergers } \\
(\mathrm{t} \text { and } \mathrm{z} \text { tests })\end{array}$ & $\begin{array}{c}\text { Mean and median returns of } \\
\text { months with mergers } \\
\text { ( } \mathrm{t} \text { and } \mathrm{z} \text { tests })\end{array}$ \\
\hline-0.00031 & -0.00996 \\
-0.00488 & -0.01411 \\
$(-0.074)$ & $(-2.963 * * *)$ \\
$(-0.831)$ & $\left(-3.111^{* * *)}\right.$
\end{tabular}

Note: The average matching firms-adjusted returns of IPOs were calculated for each event month. The observation period counts 155 months (from January 1975 to November 1987). Months with merging activity were distinguished from months without such activity. For months with merging activity, the average adjusted return of IPOs was calculated by excluding the returns of IPO firms that merged during this month. We computed the mean and median returns of months with merger activity and the mean and median returns of months without merger activity. In order to keep statistical significance, only months with more than 50 IPO firms floated were selected. To be consistent with the model, months with non-friendly IPO takeovers were classified as months without merger (121 months: 71 months without mergers and 50 months with one or more mergers). A Student-t test and sign-z test were computed to assess the statistical significance of monthly average and median returns according to merger activity. $* * *$ indicates statistical significance at $1 \%$.

months without merger activity is not significantly different from zero. Consistent with our implication 1, these results suggest that merging activity decreases the average return of the non-merged firms. Among these non-merged firms, we find that a significant amount are low-value firms and will probably be delisted in the future for reasons related to their poor performance. For instance, over the 36 months of the observation period, 152 firms were delisted for either bankruptcy or no respect of market requirement, and among firms still traded almost $60 \%$ experiment a negative performance.

Although these results cannot explain all of the underperformance observed for the sample, it is consistent with the depreciating effect of the merged firms on the average return of the non-merged firms. It appears that one part of the long run underperformance is induced by merging activity.

\section{Conclusion}

The article developed a model of IPO underpricing and 
underperformance and defined a rational context in which these two phenomena occur simultaneously.

Underpricing is caused by the presence of uninformed investors. Underperformance results from the delisting of the high-type firm that prefers to be taken over and merge, rather than invest and bear the undervaluation of its shares. After the delisting of high-type firms, only low-type firms remain on the market. To our knowledge, this finding has not yet been tested empirically.

The model predicts that strong underpricing occurs during periods of high demand by uninformed investors, and when numerous low-type firms issue. The resulting delisting of high-type firms leads to more frequent underperformance.

A preliminary empirical study allows us to validate the basic idea of this paper. The IPO companies that merged present a strong long run over-performance indicating that they are not affected by the underperformance phenomenon. Moreover, we verified that one part of the long run underperformance observed for the total sample is generated by this merging activity. Merging activity creates a depreciation effect on the monthly average return of the non-merged firms.

Accepted by: Prof. R. Taffler, Guest Editor, February 2009

Prof. P. Theodossiou, Editor-in-Chief, February 2009

\section{Appendix}

Proof of Proposition 1: Underpricing exists if and only if $P_{1}>P_{0}$. This can be shown easily:

$$
\begin{gathered}
p(\bar{v}) A>\frac{A\left[\frac{\beta}{N} p(g) p_{1}(\bar{v} \mid g)+(1-p(g)) p_{1}(\bar{v} \mid b)\right]}{1-p(g)\left(1-\frac{\beta}{N}\right)} \\
\frac{\beta}{N} p(g)\left(p(\nabla)-p_{1}(\nabla \mid g)\right)>(1-p(g))\left(p_{1}(\nabla \mid b)-p(\nabla)\right) \\
\frac{\beta}{N}<1
\end{gathered}
$$


As $\frac{\beta}{N}<1$, meaning that the offer price is rationed, the underpricing exists. Q.E.D.

Proof of Proposition 4: The first part of the theorem (i) states that both types of firm will issue the same part of their share $\beta$ at the same price $P_{0}$. This result emerges from Proposition 1 .

The second part of the theorem (ii) specifies each firm's strategy at Period 2. The high-type firm prefers to merge according to the result of proposition 3 . The low-type firm that has received a bad signal always invests, as shown in proposition 2.

Since investors are aware of the composition of manager-owner wealth at Period 0 , they can infer the strategies undertaken by firms and update their beliefs (expressed by the likelihoods in equations 5, 6, 19 and 20) according to Bayes' rule. Q.E.D.

\section{References}

Aggrawal, A., and Jaffe, J. 2003. Do Takeover Targets Under-perform? Evidence from Operating and Stock Returns. Journal of Financial and Quantitative Analysis 38(4): 721-746.

Allen, F., and Faulhaber, G. 1989. Signaling by Underpricing in the IPO Market. Journal of Financial Economics 23: 303-323.

Ang, J., and Brau, J. 2003. Concealing and Confounding Adverse Signals: Insider Wealth-Maximising Behavior in the IPO Process. Journal of Financial Economics 67(1): 149-172.

Beatty, R., and Ritter, J. 1986. Investment Banking, Reputation, and the Underpricing of Initial Public Offerings. Journal of Financial Economics 15: 213-232.

Benninga, S.; Helmantel, M.; and Sarig, O. 2005. The Timing of Initial Public Offerings. Journal of Financial Economics 75(1): 115-132.

Benveniste, L., and Spindt, P. 1989. How Investment Bankers Determine the Offer Price and Allocation of Initial Public Offerings. Journal of Financial Economics 24: 343-362.

Bhabra, H., and Pettway, R. 2003. IPO Prospectus Information and Subsequent Performance. Financial Review 38(3): 369-397.

Booth, J., and Chua, L. 1996. Ownership Dispersion, Costly Information, and IPO Underpricing. Journal of Financial Economics 41: 249-289.

Bradley, M. 1980. Interfirm Tender Offers and the Market for Corporate Control. Journal of Business 53(4): 345-376.

Bradley, M.; Desai, A.; and Kim, E. 1983. The Rationale behind Interfirm Tender Offer. Journal of Financial Economics 11(1): 183-206. 
Brau, J.; Francis, B.; and Kohers, N. 2003. The Choice of IPO Versus Takeover: Empirical Evidence. Journal of Business 76(4): 583-612.

Brav, A., and Gompers, P. 1997. Myth or Reality? The Long-Run Underperformance of Initial Public Offerings: Evidence from Venture and Nonventure Capital-backed Companies. Journal of Finance 52: 1791-1821.

Carter, R., and Manaster, S. 1990. Initial Public Offerings and Underwriter Reputation. Journal of Finance 45: 1045-1067.

Demers, E., and Lewellen, K. 2003. The Marketing Role of IPOs: Evidence from Internet Stocks. Journal of Financial Economics 68(3): 413-437.

Dodd, P. 1980. Merger Proposals, Management Discretion and Stockholder Wealth. Journal of Financial Economics 8(2): 105-138.

Drake, P., and Vetsuypens, M. 1993. IPO Underpricing and Insurance Against Legal Liability. Financial Management 22: 6473.

Espenlaub, S.; Gregory, A.; and Tonks, I. 2000. Re-assessing the Long-Term Underperformance of UK Initial Public Offerings. European Financial Management 6(3): 319-342.

Fudenberg, D., and Tirole, J. 1995. Game Theory. MIT Press.

Grinblatt, M., and Hwang, C. 1989. Signaling and the Pricing of New Issues. Journal of Finance 44: 393-420.

Habib, M., and Ljungqvist, A. 2001. Underpricing and Entrepreneurial Wealth Losses in IPOs: Theory and Evidence. Review of Financial Studies 14: 433-458.

Ibbotson, R. 1975. Price Performance of Common Stock New Issues. Journal of Financial Economics 2: 235-272.

Levis, M. 1993. The Long-Run Performance of Initial Public Offerings: The UK Experience 1980-1988. Financial Management 22: 28-41.

Lewis, C.; Seward, J.; and Foster-Johnson, L. 2000. Busted IPOs and Windows of Misopportunity. Working paper. Amos Tuck School of Business Administration.

Loughran, T., and Ritter, J. 1995. The New Issues Puzzle. Journal of Finance 50: 24-51.

Loughran, T., and Ritter, J. 2002. Why Don't Issuers Get Upset About Leaving Money on the Table in IPOs? Review of Financial Studies 15(2): 413-443.

Loughran, T.; Ritter, J.; and Rydqvist, K. 1994. Initial Public Offerings: International Insights. Pacific-Basin Finance Journal 2: 165-199.

Mauer, D., and Senbet, L. 1992. The Effect of the Secondary Market on the Pricing of Initial Public Offerings: Theory and Evidence. Journal of Financial and Quantitative Analysis 27: 55-80.

Mello, A., and Parsons, J. 1998. Going Public and the Ownership Structure of the Firm. Journal of Financial Economics 49: 79-109.

Michaely, R., and Shaw, W. 1994. The Pricing of Initial Public Offerings: Tests of Adverse-Selection and Signaling Theories. Review of Financial Studies 7(2): 279-319.

Myers, S., and Majluf, N. 1984. Corporate Financing and Investment Decisions 
When Firms Have Information that Investors do not Have. Journal of Financial Economics 13: 187-221.

Rajan, R., and Servaes, H. 1997. Analyst Following of Initial Public Offerings. Journal of Finance 52: 507-529.

Ritter, J. 1984. The 'Hot Issue' Market of 1980. Journal of Business 57: 215-241.

Ritter, J. 1991. The Long-Run Performance of Initial Public Offerings. Journal of Finance 46: 3-27.

Ritter, J. 2002. Investment Banking and Securities Issuance. Chapter 9. In M. Constantinides et al., Eds. Handbook of the Economics of Finance. Amsterdam: Elsevier Publishing.

Ritter, J., and Welch, I. 2002. A Review of IPO Activity, Pricing, and Allocations. Journal of Finance 57: 1795-1828.

Rock, K. 1986. Why New Issues are Underpriced. Journal of Financial Economics 15: 187-212.

Schultz, P. 2003. Pseudo Market Timing and the Long-Run Underperformance of IPOs. Journal of Finance 58(2): 483-518.

Seguin, P., and Smoller, M. 1997. Share Price and Mortality: An Empirical Evaluation of Newly Listed Nasdaq Stocks. Journal of Financial Economics 45: 333-363.

Shleifer, A., and Vishny, R. 1990. The Takeover Wave of 1980s. Science 249(4970): 745-749.

Stehle, R.; Ehrhardt, O.; and Przyborowsky, R. 2000. Long-Run Stock Performance of German Initial Public Offerings and Seasoned Equity Issues. European Financial Management 6(2): 173-196.

Teoh, S.; Welch, I.; and Wong, T. 1998. Earnings Management and the Long-Run Market Performance of Initial Public Offerings. Journal of Finance 53: 1935-1974.

Teoh, S., and Wong, T. 2002. Why new issues and high-accrual firms underperform: The role of analysts' credulity. Review of Financial Studies 15: 869-900.

Tinic, S. 1988. Anatomy of Initial Public Offering of Common Stock. Journal of Finance 43: 789-822.

Welch, I. 1989. Seasoned Offerings, Imitation Costs, and the Underpricing of Initial Public Offerings. Journal of Finance 44: 421-449.

Welch, I. 1992. Sequential Sales, Learning, and Cascades. Journal of Finance 47: 695-732.

Zingales, L. 1995. Insider Ownership and the Decision to Go Public. Review of Economic Studies 62: 425-448. 